University of California, Hastings College of the Law UC Hastings Scholarship Repository

Faculty Scholarship

1991

\title{
Dissolving the Sameness/Difference Debate: A Post-Modern Path Beyond Essentialism in Feminist and Critical Race Theory
}

Joan C. Williams

UC Hastings College of the Law, williams@uchastings.edu

Follow this and additional works at: http://repository.uchastings.edu/faculty_scholarship

Part of the Law and Gender Commons

\section{Recommended Citation}

Joan C. Williams, Dissolving the Sameness/Difference Debate: A Post-Modern Path Beyond Essentialism in Feminist and Critical Race Theory, 1991 Duke L.J. 296 (1991).

Available at: http://repository.uchastings.edu/faculty_scholarship/796

This Article is brought to you for free and open access by UC Hastings Scholarship Repository. It has been accepted for inclusion in Faculty Scholarship by an authorized administrator of UC Hastings Scholarship Repository. For more information, please contact marcusc@uchastings.edu. 


\section{Faculty Publications \\ UC Hastings College of the Law Library}

Author: Joan C. Williams

Source: $\quad$ Duke Law Journal

Citation: 1991 Duke L.J. 296 (1991).

Title: $\quad$ Dissolving the Sameness/Difference Debate: A Post-Modern Path Beyond Essentialism in Feminist and Critical Race Theory

Originally published in DUKE LAW JOURNAL. This article is reprinted with permission from DUKE LAW JOURNAL and Duke University School of Law. 


\title{
DISSOLVING THE SAMENESS/DIFFERENCE DEBATE: A POST-MODERN PATH BEYOND ESSENTIALISM IN FEMINIST AND CRITICAL RACE THEORY
}

\author{
JOAN C. WILLIAMS*
}

\section{A Tale of Two Controversies}

[The negro] is too radically different froin the white man in his mental and einotional structure ever to be more than a spurious and uneasy imitation of him, if he persists in following this direction. His soul contains riches which can come to fruition only if he retains intact the full spate of his einotional awareness, and uses unswervingly the artistic endowments which nature has given him.

\section{Paul Robeson ${ }^{1}$}

I have no wish to be the victim of the Fraud of a black world.

My life should not be devoted to drawing up the balance sheet of Negro values.

There is no white world, there is no white ethic, any more than there is a white intelligence.

\section{Franz Fanon ${ }^{2}$}

Are African-Americans basically the same or basically different from European-Americans? Are women basically the same or basically different from men? This Essay examines two controversies in an attempt to move beyond the parallel debates over sameness and difference

* Professor of Law, The American University, Washington College of Law. B.A. 1974, Yale University; J.D./M.C.P. 1980, Harvard Law School/Massachusetts Institute of Technology. Kathryn Abrams and Angela Harris generously took time from their busy sehedules to comment extensively on prior drafts. Additional comments by Richard Delgado, Dwight Green, and Dorothy Ross were also very helpful in guiding my thinking. Many thanks as well to Dana Lesemann, Lisa Smith, Anuja Guleria, and others who organized the Frontiers of Legal Thought Conference, and to Jennifer Alvey and other nembers of the Duke Law Journal for editing. Fimally, thanks to Tracy Hanser and Melissa Vogrin for their research assistance.

This Essay is dedicated to the menory of Mary Joe Frug (1941-1991), whose path-breaking work on work/family conflict helped found feninist jurisprudence. We will miss her.

1. Robeson, The Culture of the Negro, SPECTATOR (London), June 15, 1934, at 916, reprinted in Paul Robeson Speaks 86 (P. Foner ed. 1978).

2. F. FAnON, BLACK Skin, White MASks 227, 229 (C. Markmann trans. 1967). These epigrams are quoted in Brewer, Introduction: Choosing Sides in the Racial Critiques Debate, 103 HARV. L. REV. 1844 (1990). 
that have split femimists and African-Americans for much of this century. ${ }^{3}$ The first is the controversy among feminists precipitated by the testimony of Rosalind Rosenberg on behalf of Sears in the case of Equal Employment Opportunity Commission v. Sears, Roebuck \& Co. ${ }^{4}$ The second is the controversy among African-American law professors precipitated by Harvard law professor Randall Kennedy's critique of the body of work by minority scholars that posits a different minority perspective. ${ }^{5}$ Botll controversies have generated tremendous depth of feeling. Rosenberg's testimiony severely stramed lier relationships within the commumity of historians, of which slie liad long been an accepted member. One historian accused her of a "betrayal"; another spoke of the incident as a tragedy. "It causes ine considerable paim to lave so inany people feeling that what I did was not in women's interest," said Rosenberg. "I've spent my whole career as a feminist and as a woman's historian."7 Kennedy, like Rosenberg, was immediately embroiled in controversy. Kennedy noted im his article that some minority scliolars had urged him to refram from publishing the piece. ${ }^{8}$ After publication, Kemiedy and the scholars lie liad criticized faccd off in highly cliarged and deeply felt exclianges. ${ }^{9}$

3. For an insightful analysis of sameness and difference argumentation in the context of race, see Peller, Race Consciousness, 1990 DukE L.J. 758. Scott Brewer's quotations show that the sameness/difference split predates the integrationist/black nationalist sphit, which is the focus of Peller's article. See Brewer, supra note 2, at 1844.

Nineteenth-century feminists used sameness and difference arguments with no sense that they were inconsistent. See N. CoTT, The Grounding of Modern Feminism 19-30 (1987). The formulation of sameness and difference as opposing viewpoints crystallized in the early twentieth century as part of the debate over protective labor legislation. Id. at 117-42.

4. 628 F. Supp. 1264 (N.D. Ill. 1986), aff'd, 839 F.2d 302 (7th Cir. 1988).

5. Kennedy, Racial Critiques of Legal Academia, 102 HARV. L. REV. 1745 (1989).

6. Sternhell, Life in the Mainstream, Ms. MAG., July 1986, at 48.

7. Id. at 91 .

8. See Kennedy, supra note 5, at 1811-12.

9. See Bell, Harvard Law Furor, N.Y. Times, Jan. 26, 1990, at A30, col. 6 (letter to the editor); Delgado, When a Story Is Just a Story: Does Voice Really Matter?, 76 VA. L. REv. 95 (1990); DiLeonardo \& Reed, Academic Poverty-Pimping. NATION, Oct. 23, 1989, at 442 (letter to the editor); Matsuda, Critical Consciousness, NATION, Nov. 27, 1989, at 622 (letter to the editor); Responses to Randall Kennedy's Racial Critiques of Legal Academia, 103 HARV. L. REV. 1844 (1990) (commentary by Scott Brewer, Milner S. Ball, Robin D. Barnes, Richard Delgado, and Leslie G. Espinoza); Rothfeld, Minority Critic Stirs Debate on Minority Writing, N.Y. Times, Jan. 5, 1990, at B6, col. 3; Wiener, Law Profs Fight the Power, Nation, Sept. 4, 1989, at 246; Wiener, Wiener Replies, NAtion, Oct. 23, 1989, at 442 (letter to the editor); Will, At Harvard Law, Intellectual Gerrymandering, Newsday, May 17, 1990, at 80 . Patricia Williams has compared the debate to a scene in Ralplt Ellison's Invisible Man, in which a prize-winning black student is compelled to wrestle other black students, and then to retrieve coins that spectators have thrown on an electrified rug. See $\mathbf{R}$. Ellison, INVISIBLE MAN 17-21 (1980). Wiliams suggested that Kennedy and those he critiqued are competing for the gold coinage of academic merit. Comments of Patricia Williams at 21st Annual Conference of Women and the Law, Mar. 23, 1990, quoted in Abrams, Hearing the Call of Stories, CALIF. L. REV. (forthcoming 1991). 
What is going on here? At the simplest level, the attention of conscientious and talented outsider ${ }^{10}$ and feminist scholars is being diverted away from the issues of sexism and racism into bitter fights among theinselves. Although these scholars' motivations have been challenged, I take no position on the various charges of greed and ambition. Instead, I explore an alternative interpretation: that these are mirror-image controversies over sameness and difference. Rosenberg argued that women are different from men because she felt that treatimg them the same would ultimately redound to their detriment. ${ }^{11}$ Kennedy argued that blacks are basically the same as whites because he feared that treating thein differently would reinforce stereotypes. ${ }^{12}$ My reading of these controversies is that Rosenberg and Kennedy are caught on opposite horns of the "difference dilemma." 13 As Martha Minow has noted, people who are different can be disadvantaged by treating them the same as others in contexts where they cannot live up to the accepted norm, as when a person in a wheelclrair is treated as if she could walk. But they can also be disadvantaged if they are treated as different in a way that reinforces traditional stereotypes. Rosenberg lias expressed the first concern; Kennedy, the second.

A close analysis of these controversies offers insights into a permcious dynanric beneatli sameness/difference debates. How do scholars whose goal is to highlight the deep structural factors that systematically disadvantage women and minorities get side-tracked into controversies over sameness and difference? What is it about the "sameness/difference" framework that causes scholars concerned with racial and gender injustice to turn that concern into arguments that the relative absence of women and minorities in desirable jobs results not from discrimination but from the "clioice" or the failings of women and minorities themselves? What is the dynamic by which the sameness/difference approach

10. Mari Matsuda used this term because, taken as a group, the "minorities" in this country in fact comprise the majority. See Matsuda, Affirmative Action and Legal Knowledge: Planting Seeds in Plowed-Up Ground, 11 HARv. Women's L.J. 1, 1 n.2 (1988); Matsuda, Public Response to Racist Speech: Considering the Victim's Story, 87 Mich. L. REv. 2320, 2323 n.15 (1989) [hereinafter Matsuda, Racist Speech]. Although Matsuda notes her dissatisfaction with the term, it has the notable advantage when applied to outsider scholars of avoiding essentialism by stressing that they are bonded not by their biological status, but by the way they interpret their experience. I continue to use the term "minority" when referring to the general population of African-American and other non-Caucasian groups.

11. Offer of Proof Concerning the Testimony of Dr. Rosalind Rosenberg, at para. 1, EEOC v. Sears, Roebuck \& Co. (No. 79-C-4373) [hereinafter Testimony] (available from author).

12. See infra note 102. Kennedy argues sameness by contesting the notion of a single minority perspective. Instead he stresses differences among ininorities. See Kennedy, supra note 5, at 1778.

13. Minow, Learning to Live with the Dilemma of Difference: Bilingual and Special Education, Law \& CONTEMP. Probs., Spring 1985, at 157, 159-60; M. Minow, Making All the DifferENCE: INCLUSION, EXCLUSION, AND AMERICAN LAW 19-23 (1990). 
causes advocacy of structural change to degenerate into a "blame the victim" argument that reinforces the status quo? These questions are discussed in Section II.

Section III examines how we can reformulate sameness and difference arguments to capture their potential for transformation while avoiding their potential vulnerabilities. To do so, we inust reformulate both sameness and difference along the lines suggested by the strain of postmodern theory that celebrates the inevitability of different perspectives rather than mourning the loss of a single, absolute truth. ${ }^{14}$ This approach helps reformulate sameness based on the insight that no two people are truly "the same" in the sense of being identical. Instead, sameness rhetoric signals a societal choice to ignore a whole series of differences for strategic reasons. Claims of sameness are not mere assertions of pre-existing similarity; they are a way of carrying on discussions about social ethics.

A post-modern approach also offers a reformulation of difference that avoids essentialism by focusing on the multiple viewpoints available to any one individual. Post-modernisin offers a description of difference in wlinch the notion of a stable set of "essential" differences between inen and woinen, European- and African-Americans-or, indeed, between any two groups-disappears.

Once sameness and difference are reforniulated in this way, sameness dissolves into difference and vice versa. Both approaches can be seen as confusing ways of encoding discussions about which differences should matter in which contexts. Post-inodern reformulations of sameness and difference can transforni the controversy over whether blacks and whites, men and women are "essentially" the same, into quite a different set of debates. The first centers around how to proceed in the face of a standard loaded against outsiders: If a frontal attack on "inale" or "white" standards is impractical, should outsiders ask for "special" treatinent, or should they avoid doing so? A second source of disagreeinent is over divergent descriptions of difference. One need not adopt the essentialist notion that gender, or race, or some other single quality defines "the" one stable category of difference to acknowledge the existence of shared patterns of experience (often linked to oppression). Yet we need to describe difference in ways that avoid essentialism and stereo-

14. I use the term "post-modern" to refer to the range of problems and solutions stemming from the critique of absolutes that I have elsewhere called "the new epistemology." See J. Williams, Critical Legal Studies: The Death of Transcendence and the Rise of the New Langdells, 62 N.Y.U. L. REV. 429, 436-64 (1987). I want to distinguish between the term "post-modern" as I use it and "post-structuralism," which is but one strand within the new epistemology. See id. at 457-64. 
types. I argue that outsider jurisprudence ${ }^{15}$ and feminist narratives have far greater potential for offering trenchant and socially useful descriptions of difference than do those of relational feminists. ${ }^{16}$

\section{SAMENess AND Difference as Evasions of the NeEd for TRANSFORMATION}

\section{A. Sameness}

I found in iny investigations of the hives of wornen lawyers that when faced with numerous deinands, inany did not feel a sense of strain or negative stress. Rather, these women found their hives exciting and drainatic. They developed greater energy when the demands proliferated, rather than feeling drained, and often did not define their situation as problematic. ${ }^{17}$

Last summer I went to the Berkshire Conference of Women in History, and was invited to an inforinal dinner at the house of a historian friend, along with an older woinan who is one of the country's nost established and prominent historians of woinen. After dinner, my friend and I were coping with three children in various stages of undress and exuberance, and the conversation eventually turned to our deep frustration at our disproportionate share of child care. On a societal scale, I argued, what is happening now is what has always happened: Women are ending up with careers subservient to the needs of their children, while their husbands perform as the kind of ideal workers inen have always had the prerogative to be.

The older woman was shocked at our bitterness, and in particular by our sense that little lias clianged. As she spoke I became aware of my own historical amnesia. I thought back to iny eighth-grade history teaclier, a Yale Ph.D. who was no doubt relegated to teaching grade school because of the unavailability of academic jobs for woinen. My teacher used to tell this story: While at Yale in the 1930s, male undergraduates linked anns to block her from walking on the paths in the Old Campus, inaking lier stumble through the snow to get on her way.

You do not understand just how inuch things have changed, older women remind ine: We couldn't even get jobs. Professionals ten years older than I (now widely known and respected) could not get work because they were women. ("I don't want to be responsible for taking a woinan froin her children," said one solicitous rejection of a now-eminent historian).

15. Again, the term is Matsuda's. See Matsuda, Racist Speech, supra note 10, at 2323.

16. See infra text accompanying notes 117-23.

17. C. EPSTEIN, WOMEN IN LAW 323 (1981). 
When these women finally did get jobs, I have no doubt that it was exhilarating to show at last what they could do-to show that they had minds as rigorous and spirits as dedicated as the men. I can see how their cry of "we are basically the same" felt vigorous, confrontative, empowering. This is the sense Cynthia Fuchs Epstein captures in her classic study of women lawyers. Her informants still felt the heat of the kitchen and the boredom of the laundry as fates narrowly escaped. From that context, I too would find the autonomy and power of a professional career exhilarating. ${ }^{18}$

Today, for many woinen, the exhilaration is gone. Work such as Arhie Hochschild's The Second Shift ${ }^{19}$ documents the mind-numbing exhaustion of women trying to perform as ideal workers while simultaneously performing for their husbands and children the kind of unpaid domestic labor that their fathers expected-and, to a substantial extent, that their husbands still expect. Studies consistently show that working wives continue to do a disproportionate amount of the child care ${ }^{20}$ and virtually all of the housework. ${ }^{21}$ As a result, einployed wives work an average of forty-four percent inore hours than do housewives. ${ }^{22}$ They have less leisure, get by on less sleep, and show many signs of stress. ${ }^{23}$ My generation of women also has to deal with the resentment engendered by promises unfulfilled. One study found that husbands of working wives spend only forty-five minutes longer each week with their kindergarten-aged children than did men married to housewives. ${ }^{24}$ Another found that, on average, husbands im two-earner families barely contribute enough domestic labor to make up for the additional work that their presence in the household creates. ${ }^{25}$

18. For a thoughtful article that analyzes the sameness/difference split as in some sense generational, see W. Williams, Notes From A First Generation, 1989 U. CHl. Legal F. 99.

19. A. Hochischild \& A. Machung, The Second Shift: Working Parents and the REVOLUTION AT HOME (1989).

20. See Miller \& Garrison, Sex Roles: The Division of Labor at Home and in the Workplace, 8 ANN. REv. Soc. 237, 240 (1982) ("All research confirms that liusbands' contributions are modest and delimited. Wives' employment does not produce role equity in the louseliold."); Barnett \& Barucl, Determinants of Fathers' Participation in Family Work, 49 J. MARriage \& FAMILY 29, 33 (1987).

21. See Baruett \& Baruch, supra note 20, at 33; Berardo, Shelian \& Leslie, A Residue of Tradition: Jobs, Careers, and Spouses' Time in Housework, 49 J. MARRIAGE \& FamILY 301, 381 (1989) (wives do $79 \%$ of housework).

22. Heath \& Ciscel, Patriarchy, Family Structure and the Exploitation of Women's Labor, $22 \mathrm{~J}$. ECON. IsSUES 781, 787 (1988). This percentage lias increased simce 1969, when the figure was $13 \%$.

23. See A. Hochschild \& A. MAChUNG, supra note 19, at 4-10.

24. See A. Szalal, P. Converse, P. Feldheim, E. Scheuch, \& P. Stone, The Uses of Time: Daily Activities of URban and Suburban Populations in Twelve Countries 668, Table B (1972), quoted in A. Hochschild \& A. MACHUNG, supra note 19, at 3.

25. See Heath \& Ciscel, supra note 22, at 788 . This is an overall figure, and, of course, does not describe all liusbands. 
In this context the appeal of sameness feminism has waned. The divorce revolution confirms the message of the gender wars within the household: Women are not the same as men. They never will be as long as they lack men's access to the gender privilege that operates in work and family life. Richer women may have access to the domestic labor of poorer women to the extent to which they want to delegate domestic tasks, but (with no exceptions in my liberal, "enlightened" circle of acquaintances) no wife has access to anything like the amount of her husband's domestic labor as her husband has to hers. ${ }^{26}$ Consequently, women are indeed different. Unlike men, they have to make trade-offs that often jeopardize their access to the two major forms of adult selfdevelopment: parenthood and work success. The key drawback of sameness arguments, as "difference" feminists point out, is that they fail to challenge the structural disadvantage for women built into "male" norms.

\section{B. Difference}

Difference feminists poimt out how sameness arguments can veil the underlying structural conditions that disadvantage woinen. Rosalind Rosenberg's experience shows how difference feminisin can have the same effeet. Rosenberg has stated that she began with a sense of outrage at women's structural disadvantage in the workplace. 27 From there she concluded that women need special help-inatermity benefits, child care-to perform as ideal workers. To make this poimt, she needed a description of difference. The one she chose attributes women's difference to their choice to eschew higher-paying jobs because of their relational values. ${ }^{28}$ The response was obvious: If you can't take the heat, stay out of the factory. Rosenberg ran into problems when she described women's predicament as a problem stemming from their psychological make-up.

How about our intuitive sense that women do make different choices witl respect to work and family? Agam, a story. Kathleen Gerson tells us of Vicki, whose ambition was to join the pohice. ${ }^{29}$ But then she got inarried, moved around to further her husband's career, and ended up working in unstimulating, dead-end jobs. Ultimately, she had children,

26. I am talking here only about families with children. Hochschild confirms my own experience, namely, that upper-middle-class childless households vary from traditional gender patterns much more frequently than do similar households with children. A. HOCHSCHILD \& A. MACHUNG, supra note 19 , at 33-58, 95-104, 127, 142-58.

27. Interviews with Rosalind Rosenberg and Alice Kessler-Harris, Women's History and EEOC v. Sears, Roebuck \& Co., 18 New Perspectives 21, 28 (1986).

28. Testimony, supra note 11 , at paras. 16-22.

29. K. Gerson, Hard Choices 18-19 (1985). 
and decided that staying home was better than working, which she had come to detest.

True, Vicki eventually "chose" family over work, but that formulation masks why. Vicki was barred from a potentially exciting job because preference "was given" to her husband's career.30 She was relegated to low-paying, low-status, and uninteresting work. Vicki's disdain for wage labor should not be romanticized and cited as evidence that she "chose" to forego work. Rather, she was blocked from potentially rewarding work by her husband's exercise of gender privilege. Her resulting decision stemmed directly from her dissatisfaction with a work life constricted by structural disadvantage. It inakes no sense to cite her "choice" as evidence that no structural disadvantage exists. ${ }^{31}$

With this as background, let us examine more closely how Rosenberg transformed evidence of structural disadvantage into evidence of choice. She started from a straw man: The EEOC's purported assertion that the disproportionately small number of women in commission sales jobs was due solely to intentional discrimination. ${ }^{32}$ There were several problems with this. One was that the EEOC did not, in fact, make the assertion she attributed to it. ${ }^{33}$ More importantly, Rosenberg's testimony implied that the EEOC slould lose unless it can prove that women's disadvantaged position at Sears was caused by discrimination alone. Rosenberg's crucial (and no doubt unconscious) step was in accepting this very pro-defendant version of Title VII law. It set lier up to argue that rigor and lonesty required her to admit that Sears should win because women's disadvantage was not attributable solely to discrimination. Sears' clever formulation used women's structural disadvantage as evidence against them.

To summarize, both sameness and difference can function as arguments that veil the structural disadvantages of women in tlie workplace, and for the same reason: both take that disadvantage as a given. Sameness arguments do so by asking only that women be allowed to partici-

30. Note the non-blaming passive; no doubt it was a "mutual decision."

31. Gerson's fascinating study explores the variety and complexity of women's work/family decisions. The pattern Vicki illustrates is only one of several that Gerson describes. K. GERson, supra note 29 , at 11-22.

32. The EEOC in fact acknowledged that proportionately fewer women than men were interested in the sales jobs at issue, and controlled for sex differences by isolating the subgroup of female applicants similar to the males on a number of different background characteristics. See Schultz, Telling Stories About Women and Work: Judicial Interpretations of Sex Segregation in the Workplace in Title VII Cases Raising the Lack of Interest Argument, 103 HARV. L. REV. 1749, 1808-09 (1990).

33. For extended considerations of women's "choices" with respect to wage labor, see Schultz, supra note 32; J. Williams, Gender Wars: Selfless Mothers in the Republic of Choice, 66 N.Y.U. L. REV. (1991) (forthcoming). 
pate in the current discriminatory systein in which males have access to gender privilege that women lack; difference arguments do so when they turn evidence of structural disadvantage into evidence of women's "choice."

Kennedy, like Rosenberg, uses evidence of structural disadvantage against the victims of that disadvantage, through his argument that imnorities do not meet "objective" standards. The "objective" standard Kennedy focuses upon is the notion of ineritocracy, expressed in the context of legal acadermics as "excellent grades, ${ }^{34}$ selection to law review, a law review note, and high-level clerkships." 35 Although Kennedy acknowledges that " $[r]$ esults indicating that a given standard disadvantages the inembers of one group relative to others may indicate that the standard itself needs reform," this is not a possibility that arrests his attention. ${ }^{36}$ Instead, in a manner characteristic of the sameness/difference debate, he continues: "On the other hand, statistics may indicate that those who failed to satisfy the criteria in question are themselves in need of reform." 37 Although Kennedy does not deny the existence of discrimination, he never explores the possibility that the traditional criteria for selecting law professors are flawed. He focuses instead on "other, probably more telling, explanations" for why minority applicants fail to meet these standards, notably "structural imequalities that produce racially disparate patterns of poverty, schooling, crime, and lifestyle decisions," minorities' choice, and a "tendency to avoid intellectual engagement." 38 Unlike Rosenberg, Kennedy kept evidence of structural disadvantage separate froin choice; like Rosenberg, he used both as part of a blamethe-victim explanation that proceeded from his strategic decision to avoid challenging the structures that produce "merit" in academics.

In the context of both race and gender, scholars drawn into the sameness/difference debate often find themselves deflected from an anal-

34. Kennedy glosses over an additional qualification: "excellent grades" at an elite school.

35. Kennedy, supra note 5, at 1762 . Studies link class and ethnicity with attendance at elite law schools, see Pipkin, The Effects of Social Origin in the Allocation of Law Students, J. LEGAL Educ. 385,386 (1984) ("if students came from families that were neither affluent nor professional, they were $59 \%$ less likely to attend an elite law school than someone from families with both those characteristics"), and with admission to law school generally, see Erlanger, Toward a Sociology of Law School Admissions, 34 J. LEGAL EDUc. 374, 378 (1984) ("freshmen identifying themselves 'prelaw students' are much more likely than other freshmen to come from families with incomes of more than $\$ 35,000$ [ $53 \%$ of pre-law students, compared to $32 \%$ of all students]). They also suggest that non-Caucasians are disadvantaged by law schools' reliance on the LSAT. See Hathaway, The Mythical Meritocracy of Law School Admissions, 34 J. LEGal Educ. 86, 93 (1984).

36. For an assessment of how law scliool hiring standards disadvantage women, see Abrams, Hiring Women, 14 S. ILL. U. L.J. 487 (1990).

37. Kennedy, supra note 5 , at 1763.

38. Id. at $1768-69$. 
ysis of how minorities and women are pervasively and systematically disadvantaged by "neutral" standards. Scholars who argue from a sameness position, as well as those who argue from difference, ultimately concede the legitimacy of such structural disadvantage by arguing that outsiders can do as well as "anyone else" if ouly given the chance (the sameness position), or that they should be given special treatment because they can't hive up to societal standards designed without them in mind (the difference position). ${ }^{39}$

Both sameness and difference advocates act at times as if the opposite strategy will mevitably backfire. In fact, both sameness and difference are equally vulnerable to being used to reinforce the status quo, and for the same reason: neither formulates a direct challenge to the structures that disadvantage outsiders. Women will remam economically marginalized until wage labor is restructured, 40 and sexually subordmated until the eroticization of dominance and submission is replaced with a healthier sexuality. ${ }^{41}$ Minorities will be subject to racism until racism is disentangled from the "legitimate" power dynamic in this country. ${ }^{42}$ To join our society on anything like equal terms, minorities and women must demand neither mere entry nor special accommodation. Instead, they must demand transformation. ${ }^{43}$ One crucial message of Sears and the Racial Critiques debate is that both sameness and difference arguments will be used to remforce the status quo to the extent they are not used to challenge it. ${ }^{44}$

39. C. MacKinnon, Difference and Dominance: On Sex Discrimination, in FemInISM UNMODIFIED 32, 37 (1987).

40. See J. Williams, Deconstructing Gender, 87 M1CH. L. REv. 797, $822-36$ (1989).

41. See C. MacKinnon, supra note 39, at 127-213.

42. See Crenshaw, Race, Reform, and Retrenchment: Transformation and Legitimation in Antidiscrimination Law, 101 HARV. L. Rev. 1331 (1988).

43. For Catharine MacKinnon's similar critique of the sameness/difference paradigm, see C. MACKINNON, supra note 39, at 32. Nevertheless, a high proportion of feminists (and women in general) still think of gender in terms of sameness or difference. The following section attenpts to provide a narrative that shows such women how the sameness/difference dichotomy fails to capture their experience.

44. I suspect MacKinnon overestinates the possibility of getting women to adopt a language of douninance formed in the Marxist tradition. That language can jolt women to defensiveness about their intimate relationships and life choices as often as it inoves them to agree. See Abrams, supra note 34, at 792-98. MacKinnon's highly confrontational style can play a vital role, but it needs to be linked with a more approachable language that meets women on their own terms: on the sameness/ difference territory that they feel "naturally" captures their experience of gender.

Mackinnon also underestimates the extent to which sameness and difference arguments are inevitable to the extent that women or other outsiders choose to operate within the liberal tradition. Immediate deconstruction of the male standard is often not a possibility in litigation and a wide variety of other contexts. See infra text accompanying notes 57-58. Consequently, we are forced to clain either sameness or difference. Indeed, this is true of MacKinnon herself. The test she has advocated (allowing special treatment of women to the extent that such treatment challenges woinen's traditional subordination) is in a very real sense a difference position. See, e.g., C. MACKIN- 


\section{A POST-MOdeRn Reformulation OF SAMENESS AND DIFFERENCE}

Although both sameness and difference arguments have potential as strategies of transformation, both need to be reformulated to avoid their potential to reinforce the status quo. Let me start the process of reformulating sameness and difference with a story. I was having lunch with a friend at the faculty club of my umiversity. At the time, he and his wife had two children under three years of age, an experience that struck both of us as miserable. Yet the more he talked, the more I felt how "male" his reaction was. I am not sure why anymore, but it had something to do with his attitudes towards work and family. Then the topic shifted to birth control; his reaction struck me as shockingly Catholic. We proceeded through the lunch line and he bantered with the cashier-and I recognized a mixture of tension and camaraderie that $I$ attributed to the complex dynamic between privileged and working-class blacks, complicated by a sexual flirtation that I had never seen before, though I had often been through the line with white male colleagues. (There was probably more camaraderie and less tension in the reaction I saw because my friend is handsoine and personable.) Then we sat down, talked about scholarship for a while and he struck me as just another upper-1middleclass academic like myself.

For me, that lunch dissolved the sameness/difference debate. On the one hand, it dramatized the truth of anti-essentialism. My friend does not have "a" minority perspective, he has inany different perspectives: male, Cathohic, upper-middle-class black, upper-middle-class generic, upper-middle-class academic. Which one is relevant depends on the situation: what he is discussing or doing, and with whom. To reify his viewpoint as "black" (or "male") is to inake a set of extrenely troubling value choices by silencing all the ways in which his life is shaped by forces other than his race (or sex). Now, at solne level, one can interpret every other category in terms of his race and say he reacted as a black Catholic, a black academic, etc. And sometmies I do feel that he is reacting as a black Catholic, but not always. Note that the only context in which I felt the need to use what I think of as "junction categories" was to describe his interaction with a fellow African-American of lower status. ${ }^{45}$ This is a concrete way to illustrate iny rejection of a single Afri-

Non, Sexual Harassment of Working Women: A CaSe of Sex Discrimination 100-41 (1979); C. MACKINNON, supra note 39, at 35-36. This analysis is spelled out in J. Williams, supra note 40 , at $839-40$.

45. Kimberlé Crenshaw calls this phenomenon "intersectionality." See Crenslaw, Demarginalizing the Intersection of Race and Sex: A Black Feminist Critique of Antidiscrimination Doctrine, Feminist Theory and Antiracist Policies, 1989 U. CHI. Legal F. 139, 140. 
can-American voice, much less one minority voice, because the interaction of two Hispanics or two Asian-Americans would have been unutterably different.

Yet if my analysis dramatizes the contingency of categories, and warns against reifying any one category as being always of interpretive importance, it also expresses certain value judgments about what are the most useful categories for interpreting this sequence of events. The categories that I chose do not strike me as controversial (though I am not the best judge of this; I chose them because they seened "obvious" to me). But it is useful to note that I focused on race, class, and gender-the traditional troika of American social commentary-with retigion added, an overlooked but vital engine of American life. The traditional troika reflects the realities of power in American life, and thus draniatizes Foucault's insistence on the links between knowledge and power. ${ }^{46} \mathrm{My}$ choice of those categories suggests a new way to interpret difference. Claims of difference simply inean that in some contexts gender or race may shape (or even determine) one's outlook. This reformulation of difference, which we could call post-modern difference, avoids essentialism because it refuses to concede that race, gender-or, indecd, any given category-will always be determinative. It allows us to argue that, although race and gender may prove determinative in some particular context, this is a far cry from a reified "minority perspective" or "women's voice" that determines how a given individual will react in every situation.

This post-modern approach starts from the notion of a fragmented and shifting self. Sometimes I feel like a white, soinetimes a heterosexual, sometimes a Jew; soinetimes a lawyer, soinetimes an Episcopalian. Often I feel simply like my mother's daughter. A post-modern approach to difference highlights that each person is einbedded in a matrix of social and psychological factors that interact in different contexts. ${ }^{47}$ Essentialisin dissolves before the notion of a shifting, constantly reconfigured self,

46. M. Foucault, Power/KNowledge: Selected Interviews \& Other Writings, 1972-1977, at 109-33 (1980).

47. This theme has been movingly developed by Angela Harris, Mari Matsuda, and Patricia Williams. See Harris, Race and Essentialism in Feminist Legal Theory, 42 STAN. L. REv. 581 (1990) ('[W] are not born with a 'self,' but rather are composed of a welter of partial, sometimes contradictory, or even antithetical 'selves.' A united identity, if such can even exist, is a product of will, not a common destiny or national birthright."); Matsuda, When The First Quail Calls: Multiple Consciousness as Jurisprudential Method, 11 WOMEN's RTs. L. REP. 7 (1989); P. Williams, Response to Mari Matsuda, 11 WoMEN's RTS. L. REP. 11 (1989). For a fascinating exploration of the theme of identity as shifting and strategic, see Minow, Identities, 3 YALE J.L. \& HUMANITIES 97 (1991). Charles Taylor identifies the shift from the Enhightenment notion of a free, disengaged subject to a modernist notion of the self as partial and fragmentary. See C. TAYLOR, SOURCES OF THE SELF 106, $143-76,462-63$ (1989). 
shaped but not determined by meinbership in sets of social categories that crystallize power relations in America.

\section{A. Reformulating Sameness}

The basic problem with sameness arguments is the claim that people who are as "obviously" different as inen and woinen or blacks and whites are actually the same. This einbarrassinent is easy to solve if we stress not sameness but equal dignity. The basic claim ("I'm just as good as you!') need not entail a claim that I am the same as you. One only needs to say that "I will fulfill the conventional requirements for excellence in my own way-which, after all, is all anyone can ever do."

Once reformulated in this way, "sameness" entails not a claim that $A$ and $B$ are the same; 48 instead, it entails the assertion that the differences that exist shonld be irrelevant in this particular context. This approach links equality with questions of policy rather than biology.49 Ultimately, one is left with disagreements not about who is similar to whoin, but about which differences should unatter in which contexts.

This approach to sameness reflects a post-modern sensitivity to the constructedness of categories. After all, no two people are truly "the same." Thus, when we call Person A the same as Person B we are constructing a category of "sameness" that ignores a whole series of differences for strategic reasons. The assertion that A and B are "the same" is not merely an assertion of fact. Instead, it is an arguinent that the characteristics that $\mathbf{A}$ and $\mathrm{B}$ share are inore important for the purpose at issue than the ones they do not share.

Post-inodern sameness inakes it easier to see that, where woinen or minorities are not "the same," their failure often reflects their inability to ineasure up to a standard stacked agamst thein. The "ideal worker" standard is stacked against women; ehte schools' standards for law professors are stacked against those who lack access to cultural and class privileges that shape the usual path to academic "merit." This approach links saineness with power: We as outsiders are not the same because we are disinherited by our own tradition. Post-modern sameness cannot be

48. A number of feminist scholars have recently reformulated sameness in this way (ineluding Wendy Williams, perhaps the leading "sameness" scholar among American lawyers). See, e.g., W. Williams, supra note 18, at 101-05; Minow, supra note 13, at 203 ("the myth of interchangeability or sameness"); Scott, Deconstructing Equality-versus-Difference: Or, the Uses of Poststructuralist Theory for Feminism, 14 FEMINIST STUD. 33, 44 (1988) ("Equality might well be defined as deliberate indifference to specified differences.").

49. Sameness/difference arguments often, but do not inevitably, occur in the context of biological differences. Race, sex, disability, ethnicity, and age are important biological differences; class, scxual orientation, and religion are important nonbiological differences. See Minow, The Supreme Court, 1986 Term-Foreword: Justice Engendered, 101 HARV. L. REV. 10 (1987). 
reversed for use against outsiders because it does not make misleading claims that people as "obviously" different as blacks and whites, women and men, are the same. Neither is it content to leave intact supposedly neutral standards such as that of the ideal worker. Post-modern sameness makes exphicit outsiders' demand not to be disadvantaged by physical (or social) characteristics that should be irrelevant when it coines to distributing societal benefits.

\section{B. Reformulating Difference}

Because sameness feminism has been under siege for nearly a decade, the leading sameness advocate has reformulated sameness along post-modern lines. ${ }^{50}$ Difference feminists have generally not done the same with difference, despite the growing anti-essentialist critique. Thus far, the leading anti-essentialists have generally focused on the fact that descriptions of women's "difference" tend to describe white women. 51

Beyond critiquing existing descriptions of difference, how can we reformulate difference in ways that are true to outsiders' experience while avoiding essentialism? We begin once again with a post-modern sensitivity to the constructedness of categories. Traditional epistemology assumed the existence of a firm foundation, a "God's eye point of view," a truth not dependent upon human strivings. ${ }^{52}$ Non-foundationalists since the late nineteenth century have stressed the inevitability of different perspectives and different truths, starting froin the axiom that things look different from different points of view. ${ }^{53}$ Non-foundationalists argue that because every interpretation entails a viewpoint, no interpretation is final or objective. Different interpretations serve different purposes.

This outlook offers a way to dissolve difference in much the saine way that it dissolved sameness. Post-modern saineness translated arguments about physical or cultural similarity into arguments about which differences are relevant in which contexts. Post-modern difference dissolves claims about difference into arguments about which differences should matter in which contexts. Once reformulated, difference dissolves into sameness and vice versa.

One advantage of this reformulation of sameness and difference is that it shows how one can be a sameness feminist, or a Randall Keunedy,

50. See supra note 48 and accompanying text.

51. See, eg., E. Spelman, Inessential Woman 114-32 (1988); Harris, supra note 47.

52. "God's eye point of view" is Hilary Putman's term. H. Putnam, The Many Faces of REALISM 70 (1987).

53. For a discussion of the history of this idea, see J. Williams, supra note 14 , at $436-64$. 
and still acknowledge difference. ${ }^{54}$ One can believe that gender or race is not the operative category in a range of contexts without claiming that gender or race is never determinative. This is an important point because of the widespread sense that sameness feminism has been discredited because "woinen and inen obviously aren't the same."

A second advantage of a post-modern reformulation of sameness and difference is that it suggests that sameness advocates acknowledge differences and that difference advocates acknowledge sameness. The basic claim of post-modern sameness feminism is not that men and woinen (or whites and blacks) are identical, but that the importance of gender is at times overshadowed by race, class, personality, or any of a number of other factors. ${ }^{55}$ This is a position witll which, I suspect, most difference advocates would agree.

If sameness and difference feminists agree to this extent, are their disagreements illusory? Alas, no. Two important areas of contention remain.

1. Disagreement Over Strategy. One important disagreement is over strategy. Here I will limit iny discussion to the feminist context, although many of the same issues arise in the context of race.

Both sameness and difference advocates advocate disinantling of facially-neutral standards that are in fact molded around the life patterns and self-image of males. ${ }^{56}$ Yet sameness and difference advocates disagree on how to proceed if an iminediate change of the male standard is unattainable. Difference advocates opt for "special treatment"; sameness advocates opt for identical treatment. Sameness advocates charge that "special treatment" reinforces women's traditional disadvantage; difference advocates charge that denying women special treatment hurts women even more. In fact, both positions reinforce women's marginalization. Special treatment reinforces the message that "real"

54. See, eg., Kennedy, supra note 5 , at 1816 ; W. Williams, supra note 18 , at $104-05$ (sameners advocates acknowledge difference).

55. Sameness feminists traditionally claim that "differences among women-differences of race, ethnic and religious lieritage, class, age, values, personal style, sexualities, and experience-are the most salient differences." W. Williams, supra note 18 , at 105 . Conversely, difference feminists assume that gender is the most salient difference. Consider, for example, that Gilligan's discussions omit all reference to race and class, and describe women's outlook as if gender were the only determinative fact. See C. GILLIGAN, IN A DifFerenT VoICE (1982). I suggest that whether gender or some other combination of factors is the operative category of analysis (or whetler the operative category is gender in combination with other factors) depends on the particnlar context involved. The assumption among the "sameness" feninists that gender is never the determinative factor seems as nnconvincing as the assumption among the difference feminists that it virtually always is.

56. See W. Williams, supra note 18, at 108-10. A notable example is the ideal worker. See J. Williams, supra note 40 , at 822 . 
workers do not need pregnancy benefits; only "special" (more expensive, and therefore less desirable) workers do. Equal treatment reinforces women's marginalization to the extent it silences and privatizes the costs of a standard designed to privilege men.

What I have been describing, of course, is the California Federal debate. 57 That decision has been widely considered a crisis for sameness feminism, because it revealed that women were "really" different. In fact, it showed the deep split among feminists about what to do when they are forced to settle (as they often must) for half a loaf. I strongly suspect that the sameness and difference proponents could have agreed that the optimal solution entailed redefining the ideal worker as one who shoulders simultaneous parental and job responsibilities. The disagreement emerged because that solution was perceived as unattainable. In that context sameness proponents argued that employers, to meet the requirements of the law, had to offer disability benefits (including, but not limited to, maternity leaves) for both men and women. In effect, they argued that a change in a "male" standard was the only acceptable solution. Presumably, difference advocates disagreed because they felt that the courts were too likely to treat woinen "the same" not by giving disability benefits to both men and women, but by giving them to neither (thereby leaving women without maternity leaves). ${ }^{58}$

Which position is more persuasive? This is a thorny issue. But it is a very different issue than deciding whether men and women are "really" alike or "really" different. Dissolving the difference debate allows us to focus on issues of strategy instead of on fruitless discussions about the essential nature of outsiders.

2. Disagreement Over Descriptions of Difference. Although sameness and difference advocates agree on the existence of differences be-

57. California Fed. Sav. \& Loan Assoc. v. Guerra, 479 U.S. 272 (1987). California Federal is the topic of an immense amount of literature. The two most famous examples are probably Krieger \& Cooney, The Miller-Wohl Controversy: Equal Treatment, Positive Action and the Meaning of Women's Equality, 13 GOLDEN GATE U.I. REv. 513 (1983) (women should be treated differently than men), and W. Williams, Equality Riddle: Pregnancy and the Equal Treatment/Special Treatment Debate, 13 N.Y.U. REv. L. \& Soc. CHANGE 325 (1985) (women slould not be treated differently than men).

58. The "difference" brief argued that maternity leaves sliould be required for women under the Pregnancy Discrimination Act (PDA) of 1978, 42 U.S.C. $\$ 2000$ e(k) (1988), even if disability benefits were unavailable for men. Brief Amici Curiae of Coalition for Reproductive Equality in the Workplace, California Fed. Sav. \& Loan Assoc. v. Guerra, 479 U.S. 272 (1987) (No. 85-494). The "sameness" brief argued that maternity leaves could not be treated as a special case. Instead, it argued that the ouly way employers could meet the requirements of both the PDA and California state law was to offer disability leave to all workers for conditions including, but not limited to, preguancy. Brief Amici Curiae for National Organization for Women, California Federal (No. 85494). 
tween African- and European-Americans, and also between men and women, disagreement exists over what those differences entail. In this section, I critique one description of difference (relational feminism), and argue in favor of the descriptions of difference by outsider-scholars and feminist narrative scholars. ${ }^{59}$ In the process, I challenge the widely-held assumption of close parallels between outsider scholarship and relational feminism.

a. Relational feminism. Carol Gilligan describes men and women as a inatched set of mutually exclusive characteristics. ${ }^{60}$ The essentialism of her work stems from this description. Gilligan argues that men are more focused on a hierarchy of abstract rights (the "ladder"), whereas women tend to make contextualized arguments premised on the importance of relationships (the "web"). Men, she asserts, view maturity as involving separation and view imtimacy as threatening; women view Inaturity in terms of connection and responsibility and view separation as the failure of their ethic of care. ${ }^{61}$

Gilligan's description refleets a tradition of gender ideology in which inen are associated with characteristics celebrated in the hiberal tradition. Gilligan starts froin the work of Lawrence Kohlberg, which identifies the "reflective understanding of human rights" as the highest stage of human inoral development.62 Gilligan contimues this association of inen with hiberalism when she contrasts women's morality with a "Inorality of rights and noninterference" that celebrates "separation, autonoiny, individuation and natural rights" and equates "maturity with personal autonoiny."63 These words reflect the liberal image of society as a set of free-standing individuals who produce the greater good by pursuing their own self-interest. What the liberal tradition celebrates as the legitimate pursuit of self-imterest, however, Gilligan considers merely selfish. "You go about one-fourth to the others and three-fourths to yourself," says Jake, Gilligan's paradigm male. ${ }^{64}$

59. Note that these categories are somewhat artificial. For example, Patricia Williams is an outsider-scholar who writes feminist narratives. See P. Williams, Alchemical Notes: Reconstructing Ideals From Deconstructed Rights, 22 HARV. C.R.-C.L. L. REv. 401 (1987) [hereinafter P. Williams, Alchemical Notes]; P. Williams, The Obliging Shell: An Informal Essay on Formal Equal Opportunity, 87 MrCH. L. REV. 2128 (1989) [heremafter P. Williams, The Obliging Shell].

60. C. Gilligan, supra note 55 , at 160 .

61. Id.

62. Id. at 19; see also id. at $72-73$ (describing the highest level of moral development, what Kohlberg calls "postconventional," as when people embrace a "reflexive perspective on societal values").

63. Id. at 17 .

64. Id. at 35 . 
In contrast to autonomous and self-interested males, Gilligan depicts women as selfless, compassionate, and caring. Her informants rely heavily on the theme of selfiessness. "[T] with self-sacrifice," she notes, "is one of the conventions of femininity." 65 One informant described "[t] he moral person [as] one who helps others; goodness is service, meeting one's obligations and responsibilities to others, if possible without sacrificing oneself." 66 Her subjects often refer to the influence of their mothers: "endlessly giving";67 "selfless"; 68 "her mother's example of hard work, patience, and self-sacrifice." 69 This focus on selflessness shows the influence of the "moral mother" of Victorian gender ideology..$^{70}$ Domestic ideology defined notherhood as the central and defining female role, ${ }^{71}$ and linked motherhood with selflessness. By "living for others," women achieved the purity that allowed them to establish inoral reference points for their families and for society. 72

Relational feminists use the different voice to express caring and communal values in counterpoint witl the individualistic, self-interested focus of liberalisin. In so doing, they inobilize a gendered critique of possessive individualism integral to domesticity since its inception. ${ }^{73}$ Nancy Cott has called domesticity a "cri-de-coeur against modern work relations"; 74 I have called it a Marxism that you can bring home to mother. ${ }^{75}$ Domesticity from the beginning has linked gender ideology to political discourse, and has offered a native American language to critique the ceaseless pursuit of self-interest in "that bank note world." 76 Gilhgan's nodern relational feminists carry on a long tradition stretch-

65. Id. at 87.

66. Id. at $65-66$.

67. Id. at 54 .

68. Id. at 136 .

69. Id. at 93 .

70. Bloch, American Feminine Ideals in Transition: The Rise of the Moral Mother, 1795-1815, 4 FEMINIST STUD. 101, 191 (1978).

71. $I d$.

72. Id.

73. See N. Cott, The Bonds of Womanhood: "Woman's Sphere" in New England, 1780-1835 (1977); A. Douglas, The Feminization of American Culture (1977).

74. N. CorT, supra note 73 , at 70.

75. J. Williams, supra note 40 , at 820 .

76. N. CoTt, supra note 73, at 68. 
ing back to Frances Willard and Jane Addams ${ }^{77}$ when they launch critiques of mamstream institutions in the name of woinen's voice. ${ }^{78}$

This native language of critique presents two interlocking problems. One is its essentialisin. ${ }^{79}$ Its description of inen and women assumes that gender alone determines the way men and women feel about a very broad sweep of issues. ${ }^{80}$ The second problem is that its tracking of traditional stereotypes operates to marginalize women: the Sears case is a dramatic example. By linking rejection of mamstream values of competition and self-interest with a description of women's personality, Gilligan's modern reformulation of domesticity opened the way to the argument that women at Sears were too "different" to succeed in the competitive, "bank note world" of commission sales. ${ }^{81}$ The Sears case is important because it dramatized how relational femmism failed to change existing stereotypes enough to avoid the traditional pitfalls of domesticity.

b. Outsiders' different perspective. Both Randall Kennedy and the outsider-scholars he critiques have noted the parallels between relational femmists and what Kennedy calls the "racial distinctiveness thesis." 82 At one level, indeed, the parallels are striking. Each group posits a "different perspective" or "different voice," and both use that difference to lannch critique.

The parallels between the two hiteratures seem most pronounced when Kennedy focuses on Mari Matsuda's Looking to the Bottom: Criti-

77. Notable nineteenth-century examples of reformers who used the language of domesticity are Frances Willard (of the Women's Christian Temperance Umion), see B. EPSTEIN, The Politics of Domestictry: Women, Evangelism, and Temperance IN Nineteenth-Century AMERICA 136-37 (1981), and Jane Addams, see N. Woloch, WOMEN AND THE AMERICAN EXPERIENCE 253-69 (1984). For an accessible discussion of female reformers who have used the language of domesticity, see F. GiNSBURG, CONTESTED LIVES 227-47 (1989).

78. See, e.g., K. Ferguson, The Feminist Case Against Bureaucracy (1984); Areen, Baby M Reconsidered, 76 Geo. L.J. 1741 (1988); Coombs, Shared Privacy and the Fourth Amendment, or the Rights of Relationships, 75 CALIF. L. REv. 1593 (1987); Kornhauser, The Rhetoric of the Anti-Progressive Income Tax Movement: A Typical Male Reaction, 86 Mich. L. REV. 465 (1987); Menkel-Meadow, Portia in a Different Voice: Speculations on Women's Lawyering Process, 1 BerkLEY WOMEN'S L.J. 39 (1985).

79. The best-known critiques of essentialism in feminist theory include E. SPELMAN, supra note 51, and Harris, supra note 47; see also Hewitt, Beyond the Search for Sisterhood: American Women's History in the 1980's, 10 Soc. HIST. 299 (1988) (influential early anti-essentialist critique by historian of women).

80. For example, Carol Gilligan described the outlook of her informants with the sense that neither their race, class, or other characteristics mattered. They spoke with women's voice because they were women; gender apparently determined their outlook. See C. GilligaN, supra note 55, at 2.

81. For a fuller development of this argument, see J. Williams, supra note 40, at 813-21.

82. Kennedy, supra note 5 , at 1746. 
cal Legal Studies and Reparations ${ }^{83}$ in his consideration of the racial distinctiveness thesis. Matsuda argues that "those who have experienced discrimination speak with a special voice to which we should histen."84 She claims not ouly that outsiders have a distinct perspective, but that "victims of racial oppression have distinct normative insights. . . . Those who are oppressed in the present world can speak inost eloquently of a better one."85 She argues that critical legal scholars should turn to minority perspectives to ground normative primciples in a world without absolutes.

Matsuda's article states that she does "not intend to speak for the minority community,"86 and notes the risks entailed in "writing about the experiences of other races in ways that inay not ring true for some ineinbers of that race."87 Yet these qualifications, soine of which appear only in footnotes, behe the sweeping nature of her claims. ${ }^{88}$ Ultimately, like relational feminists, Matsuda veers into essentialism as a means of establishing her credentials to offer virtue to a fallen world.

Just as Gilligan ignores class and race divisions, and so imphicitly argues that gender is what "essentially" defines a person's outlook, Matsuda ignores class and gender, and implicitly argnes that race defines a person's perspective. "A minority perspective cuts across class lines. . . . [T]here is something about color that doesn't wash off as easily as class." 89

Kennedy's critique of Matsuda's essentialism is an important contribution. Kennedy joins anti-essentialist critics sucl as Elizabeth Spelman,90 Martla Minow, ${ }^{91}$ Angela Harris,92 and myself ${ }^{93}$ who have criticized essentialist claims. Not only does Kennedy extend these claims

83. Matsuda, Looking to the Bottom: Critical Legal Studies and Reparations, 22 HARv. C.R.C.L. L. REV. 323 (1987).

84. Id. at 324 .

85. Id. at 326, 346. Compare what Katharine Bartlett calls "standpoint epistemology." See Bartlett, Feminist Legal Methods, 103 HARv. L. REV. 829, 873 (1990).

86. Matsuda, supra note 83 , at 331.

87. Id. at 331-32.

88. Matsuda has recently protested against critics who, she charges, "created an essentialist voice where there is none." Matsuda, Pragmatism Modified and the False Consciousness Problem, 63 S. CAL. L. REV. 1763, 1775 n.46 (1990). As the text notes, I think the essentialism problem was there in Looking to the Bottom, supra note 83, though Matsuda's later work strives to avoid essentialism.

89. Matsuda, supra note 83 , at 361 .

90. See E. SPELMAN, supra note 51 .

91. See, e.g., Minow, Feminist Reasoning: Getting It and Losing It, 38 J. LEGAL Educ. 47 (1988).

92. See Harris, supra note 47.

93. See J. Williams, supra note 40. 
from the feminist to the racial context, he also formulates the anti-essentialist critique in a new and insightful way.

In the feminist context, perhaps the key thrust of anti-essentialism is to remind feminists of the existence of race. Thus, Spelman and Minow explore how the search for sisterhood has privileged the voice of white women. ${ }^{94}$ Harris, ${ }^{95}$ as well as Kimberlé Crenshaww ${ }^{96}$ and Judy ScalesTrent, 97 have explored how claims to speak for "women" overlook the experience of women of color.

The importance of race in American life is so obvious that it has proved to be an important heuristic for feminists. For Kennedy, no such heuristic exists, which leads him to formulate the anti-essentialist critique in different, more abstract terms. His central poimt is that one's "perspective" does not flow inevitably from minority status. ${ }^{98}$ Instead, the determinative faction is how one chooses to interpret one's experience. ${ }^{99}$ Kermedy documents the richly varied responses of minorities to American life, and stresses that the deep cominitment of a Frederick Douglass or a Harriet Tubman was not compelled by skin color or social experience; it was, rather, the product of personal courage based on one interpretation of the moral significance of race in American society. ${ }^{100}$

Kennedy's insight is a major contribution to the ongoing anti-essentialist critique. Yet the strength of Kennedy's critique of outsider-scholarship is limited by his virtually exclusive focus on Matsuda's Looking to the Bottom. In fact, the bulk of outsider-scholars' work (including later work by Matsuda herself) differs from Matsuda's initial article in both tone and content. ${ }^{101}$ As a result, nnost outsider-scholarship is not inarred by the essentialisn that characterizes both relational feminism and Matsuda's early work. In fact, outsider-scholars' work differs froin that of relational feminists in two significant ways.

94. See E. SpelmaN, supra note 51, at 3-5; Minow, supra note 91, at 49-51. Both Spelman and Minow note the importance of factors other than race and sex. See E. SPELMAN, supra note 51, at 80-113; Minow, supra note 91, at 47. Spelman in particular, however, focuses on race.

95. See Harris, supra note 47.

96. See Crenshaw, supra note 45.

97. Scales-Trent, Commonalities: On Being Black and White, Different and the Same, 2 YALE J.L. \& FEMINISM 305 (1990).

98. See Kennedy, supra note 5 , at 1799-801.

99. See J. Williams, supra note 40 , at 800 (challenging Robin West's clain that women identify with "connection" because of birthing and other biological experiences: "[I]sn't [West's thesis] true ouly if [all woinen] interpret the biological experiences West discusses in the same way she does?").

100. See Kennedy, supra note 5 , at $\mathbf{1 8 0 0 .}$

101. See Matsuda, supra note 47. I am not sure how inuch access Kennedy had to Matsuda's later work before Racial Critiques was published. For example, Matsuda's least essentialist work was published the same year as Kennedy's article. See Matsuda, supra note 47; Kennedy, supra note 5. 
First, at the simplest level, it is worth noting what outsider-scholars do not do. They do not seek to resuscitate existing cultural stereotypes, as do relational feminists. This is hardly surprising: The traditional stereotypes of African-Americans are so unambiguously insulting that they hold little conceivable attraction..$^{102}$ Although this is an important distinction between outsider-scholars and relational feminists, the second difference goes even deeper. Unlike relational feminists, outsider-scholars do not generally posit a comprehensive set of perfectly-matched differences that parallel different political traditions. Instead, the bulk of their work explores in conscientious detail the ways that the experience of discrimination has shaped the outlook of its victims. One major thrust of their work is to explore why African-Americans have a deep emotional and strategic commitment to rights talk (while such talk seems stifling, indeed pernicious, to the white critical scholars working within the tradition of radical discourse). ${ }^{103}$ Another is to communicate the outsiders' sense that civil rights gains occur ouly when they present no threat to the status of whites. ${ }^{104}$ Finally, outsider-scholarship challenges the neo-conservative claim that affirmative action is no longer necessary because America (except for a few anomalous individuals) has become a color-blind society. ${ }^{105}$ This is one inajor context in which outsider-schol-

102. Nonetheless, Kennedy fears that the "racial distinctiveness thesis" will resuscitate "archaic racial categories" by reasserting "the essentiality and virtue of a color line in the realm of legal academic thought." Kennedy, supra note 5, at 1803-04. Implicit in Kennedy's insistence on rigor and scientism may be a fear that outsider-scholars' explorations of fiction and personal narratives will reinforce the stereotype that blacks are good at art, but deficient in the kind of rigorous analytical thinking that our society takes inost seriously.

Note that this "good at emotions, not good at rational thought" charge has traditionally been leveled at both blacks and women. For a discussion of the linkage between the developinent of scientific norms and seventeenth-century inale gender ideology, see E. KELLER, REFL.ECTIONS ON GENDER AND SCIENCE 43-65 (1985).

103. For one of the earliest, and best, explorations of these themes, see Alchemical Notes, supra note 59. See also R. Williams, Taking Rights Aggressively: The Perils and Pramise of Critical Legal Theory for People of Color, 5 LAW \& INEQUALITY 103 (1987) (discussing the increasing tension between the attacks by CLS on rights theory and the pohitical goals of people of color).

104. See, e.g., Bell, Bakke, Minority Admissions, and the Usual Price of Racial Remedies, 67 CALIF. L. REV. 3, 17 (1979) (arguing that the Bakke decision furthers the interest of the white majority as much as it benefits mimorities); Delgado, On Taking Back Our Civil Rights Promises: When Equality Doesn't Compute, 1989 WIS. L. REV. 579 (statistical analysis reveals that the promise of equality is not being fulfilled).

105. See, e.g., Bell, The Supreme Court, 1984 Term-Foreword: The Civil Rights Chronicles, 99 HARV. L. REV. 4, 11-12 (1985) (attacking the complacency of the Supreme Court and challenging the Court to address all racial discrimination, whether overt or covert); Lawrence, The Id, the Ego, and Equal Protection: Reckoning with Unconscious Racism, 39 STAN. L. REV. 317, 321 (1987) (maintainimg that the discriminatory purpose standard does not adequately address unconscious racism); Matsuda, Racist Speech, supra note 10, at 2325 (arguing that only a focus on the effects of racist speech can provide an answer to eliminating it). 
ars have told stories, which are a direct and effective way to support the claim that discrimination persists.

Outsiders' stories also serve to dramatize how experiences of discrimination anger and humiliate, with corrosive psychic effects; how discrimination is a form of "spirit-murder."106 This scholarship tries to communicate the scope and urgency of the damage caused by racial ammus, often in connection with demands for remedies far more vigorous than virtually anyone before them had seriously advocated (notably reparations and bans on racial hate speech.) ${ }^{107}$ Outsider-scholars also have examined specific cases ${ }^{108}$ or incidents ${ }^{109}$ in which a person of color's reaction diverged from that expressed in the inainstream. These studies examme how the world looks from the perspective of black subcultures with distinctive attitudes toward unwed motherhood, law enforcement, and big-city politics.

We can distinguish in outsider-scholarship two quite distinct sorts of claims. One is that minorities' personal experience of discrimination yields a different perspective on rights talk, civil rights law, and other law that addresses issues of discrimination. Kennedy challenges this claim by redefining discrimination law as "race-relations law," 110 which implies that the law imvolves a dialogue between two groups about their relationship. Although I understand soine of Kennedy's notivations, this move strikes me as unhelpful. Is Kennedy really claiming that minorities' experience of discrimination does not yield a different kind of knowledge about the impact and incidence of discrimination than the kind of knowledge a white person has?"11 If so, I disagree, because I know that to

106. P. Williams, Spirit-Murdering the Messenger: The Discourse of Fingerpointing as the Law's Response to Racism, 42 U. M1AM1 L. REv. 127, 129 (1987) [hereinafter P. Williams, Spirit-Murdering]; Matsuda, Racist Speech, supra note 10, at 2335-41; see also P. Williams, On Being the Object of Property, 14 SIGNS: J. WOMEN CULTURE \& Soc'Y 5 (1988) (an autobiographical account of life as a black woman); P. Williams, supra note 47; P. Williams, The Obliging Shell, supra note 59, at 213237 (illustrating that racism persists, albeit in subtler forms).

107. See, e.g., Delgado, Words That Wound: A Tort Action for Racial Insults, Epithets, and Name-Calling, 17 HARV. C.R.-C.L. L. REv. 133 (1982); Matsuda, supra note 83, at 373-99; Matsuda, Racist Speech, supra note 10, at 2361-74. .

108. See Austin, Sapphire Boundl, 1989 WIS. L. REv. 539, 549-76.

109. See P. Williams, Spirit-Murdering, supra note 106, at 130-39; P. Williams, Alchemical Notes, supra note 59 , at $406-08$.

110. Kennedy, supra note 5 , at 1777.

111. I think le is not. "I do not mamtain that no appreciable differences exist in the prevailing opinions and sensibilities of various racial groups." Id. at 1816 (citing poll reporting that blacks and whites are "worlds apart" in their perception of race relations). Surely this difference in perspective leads to a different relationship to discrimination law. Altlough blacks liave a unique perspective on discrimination law, Kennedy is right to stress that whites do as well. After all, race relations is a key moral problem for white America, and lias been for over a century.

I sense that Kennedy's defense of whites' involvement in discrimination law reflects his response to the incident at Harvard Law School in whicl minority students objected to Harvard's invitation 
describe to even a sympathetic man the operation of gender privilege at home and work requires such constant reinterpretation of the "obvious" as to make oneself an utter bore. Outsider-scholars convince me the same is true of being African-, Asian-, Native, or other-American. Those who experience the "victim perspective"112 as part of their everyday life have a peculiar perspective and are entitled to ask society at large to listen.

Nor does Kennedy's rejection of this argument seen necessary to avoid essentialism. Outsider-sclrolars do not argue (as relational feinimists often seem to do) that the "different perspective" yields an "outsider answer" on virtually any topic. Their claim is much more himited. They claim that blacks react as blacks when they see themselves being discriminated against because they are black. This proposition does not require a claim tliat race waslies out less easily than class; only that one does not react as a Yalie when someone taunts you as a nigger.

Scholarship limited in this way presents few problems of essentialism. Essentialist descriptions of difference assume uniform characteristics within the "different" group, and are thus vulnerable to the response that it is no wonder tliat outsiders can't meet our standards, given that they are so different. Outsider-scholars avoid this because the scope of commonality they posit is much narrower than that posited by relational ferminists. Outsider-scholars claim for minorities a special insight into the dynarmics and the effects of discrimination; relational feminists claim for women a critique of mamstream institutions that many women do not share.

Yet this is not the end of the issue, for what $I$ have thus far presented as a clear-cut dichotomy actually involves more of a contin-

to Jack Greenberg (who is white) of the NAACP Legal Defense Fund to teach discrimination law. See Kennedy, supra note 5, at 1756-58. Was that fight, though, about whether minority scholars should have "proprietary claims over the study of race relations?" Id. at 1759. I would suggest it stemmed instead from the affront minority students felt in the face of Harvard's implicit decision that no black was as qualified to teach discrimination law as was Jack Greenberg. In addition, I suspect, Harvard students were outraged, particularly in view of the law school's very visible lack of commitment to hiring minority scholars, that a white scholar was hired to teach discrimination law; of all subjects. The message that blacks' experience of discrimination is not an important value-not even in a course about discrimination - could not have been more clear. Having been told in 1977with no self-consciousness whatsoever-that Harvard had only two women law professors because no others were qualified ("not one in the whole country?," I asked), I can fully understand the strong emotions elicited by the "none are available" argument at Harvard Law School. See generally Flint, Bell at Harvard: A Unique Activism, Boston Globe, May 7, 1990, Metro/Region, at 1; Flint, Jackson Offers to Mediate Harvard Dispute, Boston Globe, May 3, 1990, Metro/Region, at 27.

112. The term is Alan Freeman's. Freeman, Antidiscrimination Law: A Critical Review, in THE Politics of Law: A Progressive Critique 96, 98 (D. Kairys ed. 1982). I stress that victims are entitled to insist on others' attention not because they can offer virtue to a fallen world, but because they are experts on their own lives. Cf. Matsuda, supra note 83, at 326, 346. 
uum. For (albeit less commonly than do relational feminists) outsiderscholars do at times discuss issues that do not involve discrimination directly. Some of these, such as Patricia Williams' discussion of the incident in which New York City pohice officers killed a sixty-seven year-old black woinan in the course of evicting her from her apartment, involve discrimination just below the surface. ${ }^{113}$ But to reduce others to discrimination clouds an important issue. In Regina Austin's discussion of the Chambers case, ${ }^{114}$ in which a white-dominated charity fired an AfricanAmerican arts and crafts instructor when she decided to becoine a simgle mother, Austin is arguing that the charity's action was discriminatory, ${ }^{115}$ but (as I read her) Austin's deeper message is that we need to work hard to understand what makes sense within the framework of life choices available to African-American women of modest circumstances im this country. ${ }^{116}$ Their world looks very different, she seeins to be arguing, because of a whole series of race, class, and gender disadvantages that affect more than their experience of discrimination. They affect the pattern of their hives at a more basic level-how they decide when to have children, the names they choose, even their decisions about when and whether to buy life insurance.

This brings us back to Matsuda's point that all minorities do not share a single "different perspective." It also brings us back to the fact that women in this society differ from men in patterned ways. In the following section, I examine a strand of feminist thought that parallels the work of outsider-scholars much more closely than does relational feminism.

\section{Feminist Narratives}

Feminists have long argued that the personal is political. Current trends in legal scholarship also allow feminists to articulate the view that women's experience is so thoroughly silenced by dominant forms of discourse that de-privileged genres, such as personal narrative, inay be necessary to enable women to commumicate what they see as basic realities. From among the inany examples of feminist narrative available, ${ }^{117}$ I will

113. See P. Williams, Spirit-Murdering, supra note 106, at 130-36.

114. Chambers v. Omaha Girls Club, 629 F. Supp. 925 (D. Neb. 1986), aff'd, 834 F.2d 697 (8th Cir. 1987).

115. See Austin, supra note 108, at 549-76.

116. Id. at 546; see also Austin, The Insurance Classification Controversy, 131 U. PA. L. REv. 517,518 (1983) (illustrating how insurance company classifications based on sex and race contribute to social stratification).

117. See, e.g. P. Williams, Spirit-Murdering, supra note 106, at 128 (relating her own experience of being denied entry into a store); Estrich, Rape, 95 YALE L.J. 1087 (1986) (describing her personal experience as a victim of rape); AALS 1990 Annual Conference (Plenary Session on Outsider Per- 
focus on the work of Marie Ashe, whose work highlights the parallels between feminist narrative and outsider-scholars, as well as the differences between the outsider-scholars and relational feminists. ${ }^{118}$

Ashe's Zig-zag Stitching and the Seamless Web intertwines discussion of a broad range of cases concerning reproduction with narratives of her own five hive births and three abortions. ${ }^{119}$ Having undergone three pregnancies in the past six years, my reaction was deep and personal. In many ways, my reactions to pregnancy and birth differed markedly from Ashe's. Yet Ashe's achievement is to bring into law reviews the conversational aura of the obstetrician's office, the maternity hospital, and the birthing table. That done, she points out how hittle of that aura filters into courtrooms and cases in which the principal professional actors are often male-and, if not male, perhaps constrained (as Ashe is not) by the felt incongruity at bringing the realities of pregnancy, birth, and miscarriage into the law. We see Ashe standing in her kitchen in the middle of a miscarriage. She notes: "Purple as sun-done plums, your fine remains. . . I I have learned through miscarriage the bloodiness of abortion-spontaneous or induced. Every abortion involves violence and bloodiness." 120

Is this woman's experience in the raw? No. As post-modern thought reminds us, we cannot think without using categories for thinking, and many of the categories Ashe uses to conceptualize her experience stein from the stereotype of womanhood that pre-dated domesticity, which associated woinen with sexuality, power, and danger. (A familiar surviving expression of this stereotype is the witch.) ${ }^{121}$

Yet for all that, Ashe's approach to difference avoids many of the pitfalls of relational feminism; her descriptions of difference ultimately resemble those of outsider-scholars. Like thein, she avoids setting up matched pairs of stereotypical images that separate the mainstream from her "different" group. Like them, she focuses on contexts in which she clearly is defined by her outsider status: pregnancy, childbirth, fetal death. And, like outsider-scholars most of the time, Ashe meticulously

spectives); 21 st Annual Women and the Law Conference (Panel Discussion on Feminist Narratives).

I would like to thank Kathryn Abrams for bringing some of this literature to my attention, and both ler and Martlia Mahoney for sliaring their articles with me before publication.

118. Because of its explicit reliance on narrative, I focus on Ashe, Zig-Zag Stitching and the Seamless Web: Thoughts on "Reproduction" and the Law, 13 Nova L. REv. 355 (1989) [hereinafter Ashe, Zig-Zag Stitchingl. See also Aslie, Law-Language of Maternity: Discourse Holding Nature in Contempt, 22 N. ENG. L. REv. 521 (1988) [hereinafter Ashe, Law-Language].

119. Two of her abortions were spontaneous, one induced. See Aslie, Zig-Zag Stitching, supra note 118 , at 376 .

120. Id. at 379 .

121. For a discussion of this stereotype in the law review literature, see J. Williams, supra note 40 , at $804-05$. 
avoids overstatements about the scope of commonality she posits among women. (She is careful, for example, to note the wide divergence in women's reactions to their own abortions.) $)^{122}$

Ashe's work and that of outsider-scholars suggest ways that we can begin to explore difference without falling into old stereotypes or essentialist thinking. One key is to remain thoughtful about the threshold issue of what is the relevant category of analysis in a given situation. Another is to be wary that our descriptions of difference do not posit commonality of too sweeping a scope. A third is to ask especially searching questions when we see descriptions of difference resonant of the traditional stereotypes of the inoral inother or the witch, the mammy or the jezebel. ${ }^{123}$

Descriptions of difference inust pay close attention to context and to ideology. That should not be hard for feminists or fellow-riders, because challenge to stereotype is what feminism is all about, and contextualization is a key feminist inethodology.

\section{Conclusion}

A post-inodern approach to the debate ultimately dissolves the traditional dichotoiny between saineness and difference. Sameness claims are best viewed as pohicy arguments about which categories applicable to a given individual ought to inatter im a specific context. This revamping of the saineness argument makes it easier to link assertions about sameness with the need for transformation. If I carmot be "the same" in a context in which equality depends on sameness, this means that the "neutral" standard that I cannot live up to is not, in fact, neutral.

Post-1nodern difference also begins from the notion that a inyriad of possible categories are applicable to any individual. Assertions about difference are arguinents that a given category-sex, race, class, etc.-is likely to yield powerful interpretive results in a particular context. The categories that crystallize power relations in America (race, sex, class) will often prove indispensable to analysis of sameness. This is not to say, though, that any category will always prove important, or even relevant.

122. Ashe, Zig-Zag Stitching, supra note 118, at 371-79; see also Ashe, Law-Language, supra note 118, at 546. Despite Ashe's careful qualifications, I sometimes question whether she is sensitive to the fact that her viewpoint reflects that she-far more, I suspect, than many contemporary American women-has chosen to make the experiences of pregnancy and birthing central to her adult identity (not only has she experienced eight pregnancies, she also writes extensively about maternity). (1985).

123. See D. White, AR'n't I Woman? Female Slaves in the Plantation South 27-61 
Women do not always react as women; sometimes they react as Democrats, lesbians, bigots, or blacks. This formulation of difference shows that any assertion of a unified outlook entails an interpretive decision to reify gender, or race, or some other characteristic, to assert that the particular characteristic always overrides all other possible characteristics in importance. Without a biological link to render such an interpretive decision "objective," this approach will normally prove repressive of the complex and changing forces that shape individuals.

This analysis helps us to understand that sameness and difference are not arguments about the essential nature of human beings. Instead, they are questions that stem from the fact that "neutral" standards systematically disadvantage outsiders: The "ideal worker" standard disadvantages women; conventional notions of merit disadvantage AfricanAmericans; and both institutions and physical structures disadvantage the disabled.

If we insist on changing these standards, the need for outsiders to claim sameness or difference will disappear. Once the standard is designed with them in mind, they will simply meet it. Unfortunately, this solution is tidy in theory but difficult in practice, as Martha Minow's work has explored in such eloquence and depth. ${ }^{124}$ Until we can teach the whole class sign-language, the difference dilemma will persist.

Although we will not soon escape the difference dilemma, we can try to avoid diverting our energy into arguments amongst ourselves over whether outsiders are "really" the same or "really" different. Reformulatimg sameness and difference along post-1nodern lines largely dissolves the divergence between these two positions. Such reformulations can help refocus our attention onto two topics of abidimg concern. The first is how to describe differences between outsiders and the mamstream in ways that do not reinforce stereotypes. The second is to forge working agreeinents on the most effective strategies to pursue in the face of the supposedly "neutral" standards of a tradition that disinherits us. ${ }^{125}$

124. See M. Minow, supra note 13 .

125. See P. Williams, On Being the Object of Property, 14 SignS: J. WoMEN CULTURE \& SOC'Y 5,6 (1988). 